Check for updates

Cite this: RSC Adv., 2021, 11, 19935

Received 16th April 2021

Accepted 19th May 2021

DOI: $10.1039 / \mathrm{d} 1 \mathrm{ra0} 2975 \mathrm{~d}$

rsc.li/rsc-advances

\section{A ZnS@N-GQD nanocomposite as a highly effective and easily retrievable catalyst for the sonosynthesis of $\beta$-amino carbonyls}

\author{
Javad Safaei-Ghomi, (D) *a Mohammaed Abdulridha Mutashar ${ }^{\mathrm{b}}$ and Zahra Saharkhan ${ }^{\mathrm{a}}$ \\ A three-component reaction of acetophenone, aromatic aldehydes, and aniline derivatives has been \\ achieved in the presence of a ZnSanitrogen graphene quantum dot (N-GQD) nanocomposite as a highly \\ effective heterogeneous catalyst to produce $\beta$-amino carbonyls. The catalyst has been characterized by \\ XRD, SEM, TEM, FT-IR spectroscopy, EDS, BET and TGA techniques. The feasibility of carrying out the \\ one-pot synthesis under ultrasonic irradiation with a heterogeneous nanocatalyst could improve the \\ reaction rates and shorten the reaction times.
}

\section{Introduction}

$\beta$-Amino carbonyls have biological properties including anticancer, ${ }^{1}$ anti-diabetes, ${ }^{2}$ antibacterial, antioxidant, ${ }^{3}$ antifungal, ${ }^{4}$ anti-virus, ${ }^{5,6}$ and non-steroidal progesterone receptor antagonists. ${ }^{7}$ Therefore, searching for effective methods for the synthesis of $\beta$-amino carbonyls is an attractive challenge. $\beta$ Amino carbonyls have been regarded as notable targets in organic syntheses. A number of ways have been mentioned for the preparation of $\beta$-amino carbonyls using diverse catalysts including $\mathrm{HClO}_{4},{ }^{8}$ phenyl boronic acid, ${ }^{9} \mathrm{Zn}(\mathrm{OTf})_{2},{ }^{10}$ indium trichloride, ${ }^{11} \mathrm{Zn}\left(\mathrm{BF}_{4}\right)_{2},{ }^{12}$ ceric ammonium nitrate, ${ }^{13}$ bismuth trichloride, ${ }^{14}$ sulfamic acid, ${ }^{15}$ sulfuric acid-modified polyethylene glycol, ${ }^{16}$ and manganese perchlorate hexahydrate. ${ }^{17}$ Each of these methods may have its own advantages but also suffer from apparent drawbacks such as prolonged reaction time, low yield, complicated work-up, or hazardous reaction conditions. Graphene quantum dots (GQDs) have numerous potential applications in electronics, ${ }^{18}$ solar cells, ${ }^{19}$ light emitting diodes, ${ }^{20}$ bioimaging, ${ }^{21}$ drug delivery, ${ }^{22}$ photocatalysts, ${ }^{23}$ sensors, ${ }^{24}$ and fuel cells. ${ }^{25}$ GQDs are carbon-based nanoscale particles that display excellent physical, chemical, and biological properties, which permit them to excel in a wide spectrum of applications in nanostructures. ${ }^{26-31}$ Sonochemistry is an essential tool in the field of synthetic organic chemistry. ${ }^{32,33}$ Sonochemistry is a very good method to synthesize organic compounds with high yields, short reaction time, and mild conditions. $^{34,35}$ The effects of ultrasonic irradiation during organic reactions is due to cavitation and then the collapse of

${ }^{a}$ Department of Organic Chemistry, Faculty of Chemistry, University of Kashan, Kashan, 51167, I. R. Iran. E-mail: safaei@kashanu.ac.ir; Fax: +98-31-55912397; Tel: +98-31-55912385

${ }^{b}$ Department of Inorganic Chemistry, Faculty of Chemistry, University of Kashan, Kashan, 51167, I. R. Iran the bubbles that produce short-lived regions with high pressure and temperature. ${ }^{36,37}$ Herein, we report the use of the ZnS@NGQD nanocomposite as a new efficient catalyst for the preparation of $\beta$-amino carbonyls via a three-component reaction of acetophenone, aromatic aldehydes, and aniline derivatives under ultrasonic irradiation (Scheme 1).

\section{Results and discussion}

We prepared a ZnS@N-GQD nanocomposite via easy techniques. The XRD patterns of nano-ZnS and ZnS@N-GQD nanocomposite are shown in Fig. 1. The XRD patterns confirm the presence of ZnS (JCPDS no. 77-2100). XRD results have been supported by literature. ${ }^{38-45} \mathrm{~A}$ peak appearing at $27.3^{\circ}$ can be indexed to the reflection of the hexagonal wurtzite phase..$^{39}$ The peaks at $47^{\circ}$ and $57^{\circ}$ are attributed to nano-ZnS. ${ }^{39} \mathrm{XRD}$ of the ZnS@N-GQD nanocomposite shows peaks at $11^{\circ}$ and $24.5^{\circ}$ that correspond to the planes of graphene structures. ${ }^{42-46}$ There is also a peak appearing in the range of $17-22^{\circ}$, corresponding the $d$-spacing of $0.37-0.52 \mathrm{~nm}^{.4-46}$ Maybe other peaks in the XRD pattern of ZnS@N-GQDs are related to irregular carbon structures. ${ }^{47,48}$

In order to investigate the morphology and particle size of the nanocomposite, the SEM (scanning electron microscopy) image of the ZnS@N-GQD nanocomposite is displayed in Fig. 2. The SEM image indicates particles with diameters in the range of nanometers. The high-resolution transmission electron microscopy (HRTEM) (Fig. 3) image of the ZnS@N-GQD

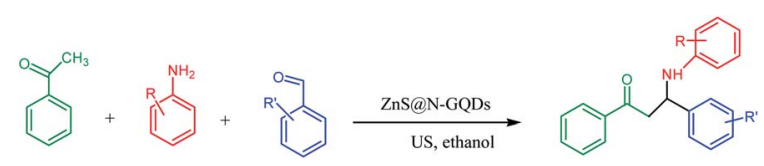

Scheme 1 Preparation of $\beta$-amino carbonyls using the ZnS@N-GQD nanocatalyst. 


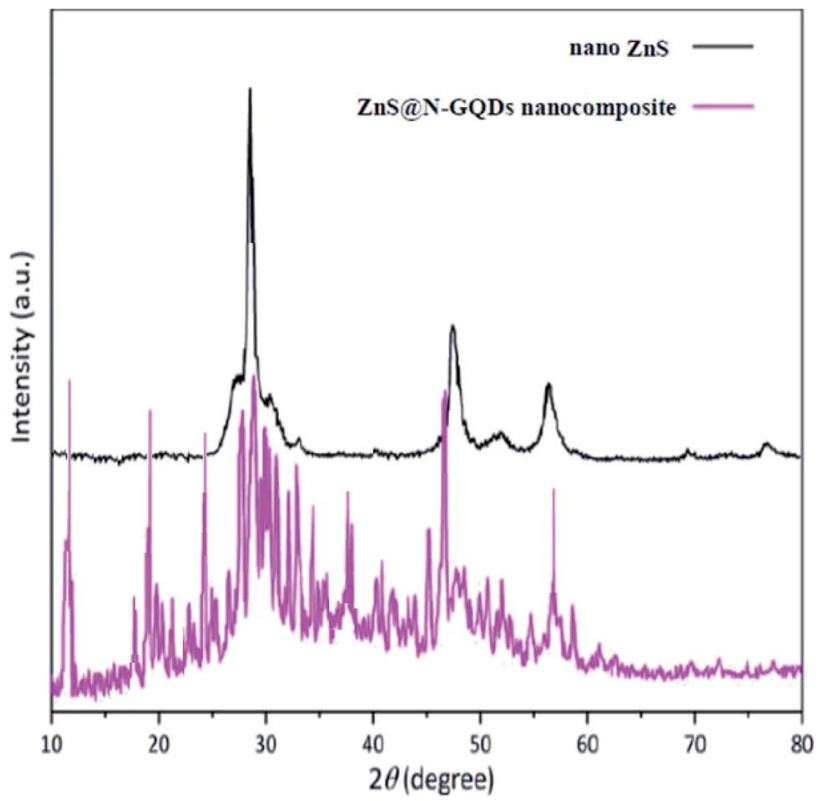

Fig. 1 XRD pattern of the ZnS@N-GQD nanocomposite.

nanocomposite indicated that the as-prepared nanocomposites were crystalline with lattice spacing in the range of nanometers. Note that the ZnS arrays had a rough surface that can be appropriate for the immobilization of N-GQDs. The energy-dispersive Xray spectrum (EDS) confirmed the presence of $\mathrm{Zn}, \mathrm{S}, \mathrm{O}, \mathrm{N}$ and $\mathrm{C}$ species in the structure of the nanocomposite (Fig. 4).

FT-IR spectra of ZnS and the ZnS@N-GQD nanocomposite are shown in Fig. 5. The absorption peaks at 1600 and $3400 \mathrm{~cm}^{-1}$ are attributed to the bending and stretching vibrational absorptions of $\mathrm{OH}$, respectively. The peak at $600 \mathrm{~cm}^{-1}$ corresponded to $\mathrm{Zn}-\mathrm{S}$. The characteristic peaks at $3434 \mathrm{~cm}^{-1}(\mathrm{O}-\mathrm{H}$ stretching vibration), $1665 \mathrm{~cm}^{-1}$ ( $\mathrm{C}=\mathrm{O}$ stretching vibration), $1103 \mathrm{~cm}^{-1}$ (C-O-C stretching vibration) appear in the spectrum of Fig. 5. The peak at approximately $1470-1582 \mathrm{~cm}^{-1}$ is attributed to $\mathrm{C}=\mathrm{C}$ bonds.

The results for $\mathrm{N}_{2}$ adsorption-desorption containing the BET surface area $\left(S_{\mathrm{BET}}\right)$ and the total pore volumes $\left(V_{\text {total }}\right)$ of the $\mathrm{ZnS}$

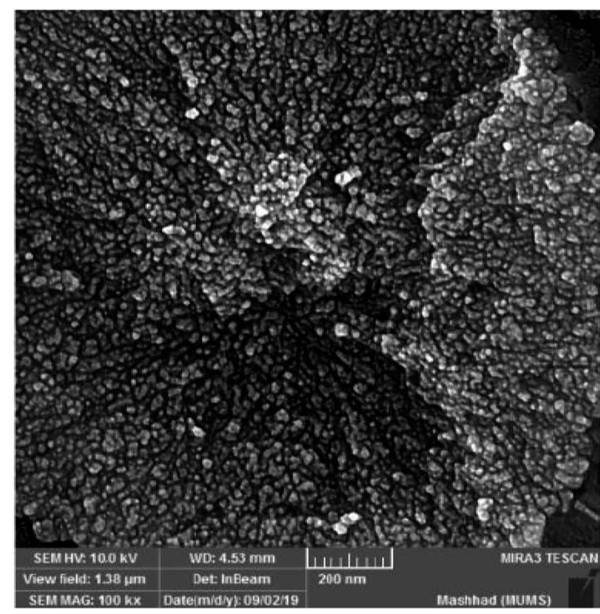

Fig. 2 SEM image of the ZnS@N-GQD nanocomposite.

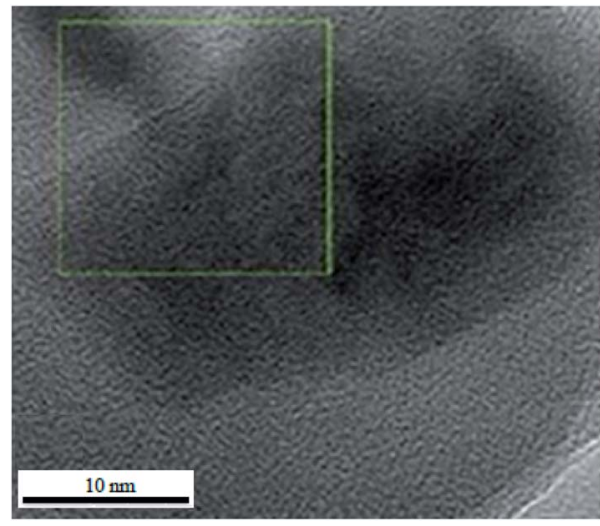

Fig. 3 HRTEM of the ZnS@N-GQD nanocomposite.

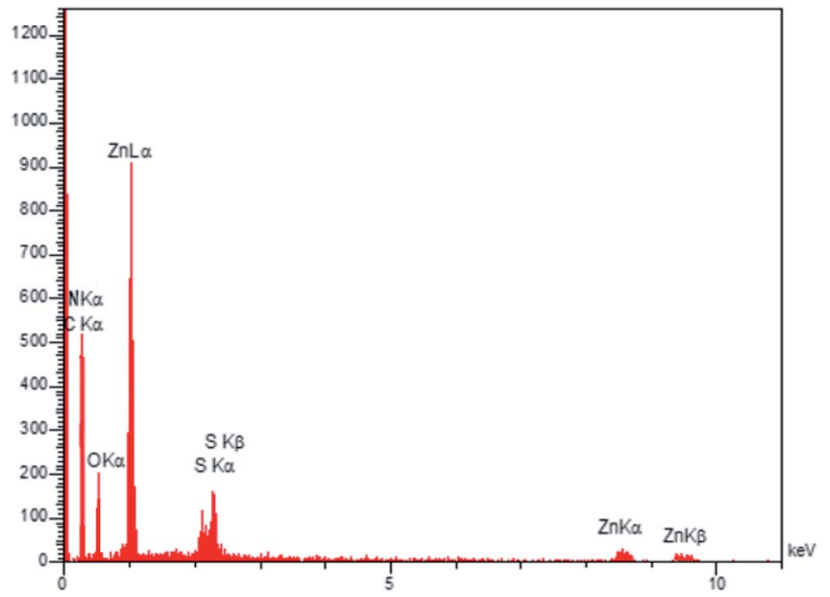

Fig. 4 EDS image of the ZnS@N-GQD nanocomposite.

and ZnS@N-GQD nanocomposite are summarized in Table 1. The results presented that the BET specific surface area of ZnS was improved from 5.18 to $14.90 \mathrm{~m}^{2} \mathrm{~g}^{-1}$ after modification with

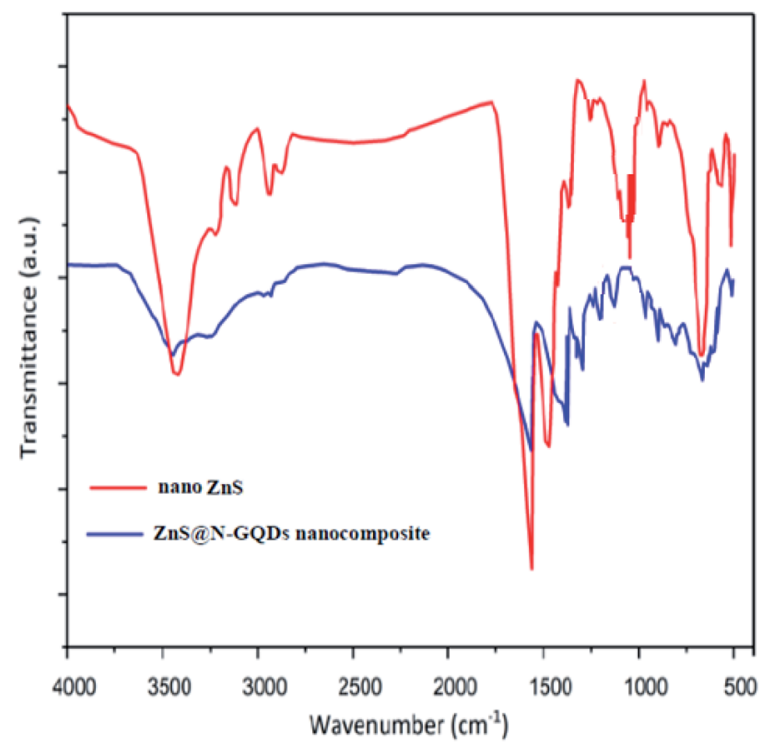

Fig. 5 FT-IR spectra of ZnS and the ZnS@N-GQD nanocomposite. 
Table 1 BET surface area $\left(S_{\mathrm{BET}}\right)$ and the total pore volumes $\left(V_{\text {total }}\right)$ of the nanostructures

\begin{tabular}{lcl}
\hline Materials & $S_{\mathrm{BET}}\left(\mathrm{m}^{2} \mathrm{~g}^{-1}\right)$ & $V_{\text {total }}\left(\mathrm{cm}^{3} \mathrm{~g}^{-1}\right)$ \\
\hline Nano-ZnS & 5.18 & 0.08 \\
ZnS@N-GQD & 14.90 & 0.15 \\
nanocomposite & &
\end{tabular}

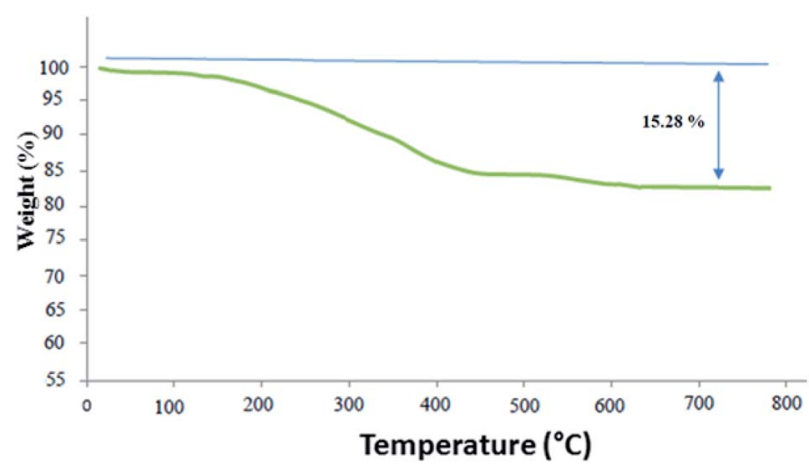

Fig. 6 TGA of the ZnS@N-GQD nanocomposite.

GQDs; therefore, more active sites were introduced on the nanostructure surface.

Thermogravimetric analysis (TGA) considers the thermal stability of the ZnS@N-GQD nanocomposite (Fig. 6). The weight loss $(2.05 \%)$ at temperatures below $200{ }^{\circ} \mathrm{C}$ is due to the removal of the physically adsorbed solvent and surface hydroxyl groups. The curve displays a weight loss about $13.23 \%$ from $200{ }^{\circ} \mathrm{C}$ to $700{ }^{\circ} \mathrm{C}$, which is attributed to the oxidation and degradation of N-GQDs.

Initially, we investigated the three-component reaction of acetophenone, benzaldehyde, and aniline as a model reaction.
The model reactions were performed using $\mathrm{Et}_{3} \mathrm{~N}, \mathrm{NaHSO}_{4}$, nano-ZnO, nano-ZnS and ZnS@N-GQD nanocomposite. The reactions were conducted using diverse solvents including ethanol, acetonitrile, water or dimethylformamide. The role of ultrasonic irradiation and the effects of different powers of ultrasonic irradiation $(30 \mathrm{~W}, 40 \mathrm{~W}$ and $50 \mathrm{~W})$ on the reaction were studied. The results indicated that sonication certainly affected the reaction system. It could decrease the reaction time and increase the yield of the products. When the reaction was carried out under reflux conditions (entries 6-11, Table 2), it gave lower yields of products and took longer reaction times (80 $\mathrm{min}$ ), while the same reaction was carried out under ultrasonic irradiation to give excellent yields of products in short reaction times (10 $\mathrm{min}$ ). The best results were gained in EtOH and we found that the reaction gave convincing results in the presence of the $\mathrm{ZnS@N-}$ GQD nanocomposite $(8 \mathrm{mg})$ under ultrasonic irradiation (Table 2). In further studies on catalyst loading, we recognized that the yield of compound 4a remained almost the same when $9 \mathrm{mg}$ of the ZnS@N-GQD nanocomposite was used. The use of the lower catalyst loading $(7 \mathrm{mg}$ ) afforded $4 \mathbf{4}$ in $87 \%$ yield.

The effect of electron-withdrawing and electron-donating substituents on the aromatic ring of aldehydes and aniline on the reaction yields was investigated (Table 3). Aromatic aldehydes having nitro groups reacted at a faster rate compared with aromatic aldehydes substituted with other groups.

We considered the recycling of the ZnS@N-GQD nanocomposite as a catalyst for the model reaction. The results showed that the nanocomposite can be reused several times without remarkable loss of catalytic activity (yields 93 to 90\%) (Fig. 7). For the recycling of the ZnS@N-GQD nanocomposite, the solution was filtered and the nanocatalyst was recovered. The recovered ZnS@N-GQD nanocomposite was rinsed four times with ethyl acetate and dried at $70{ }^{\circ} \mathrm{C}$ for $5 \mathrm{~h}$.

Table 2 Optimization of reaction conditions using different catalysts ${ }^{a}$

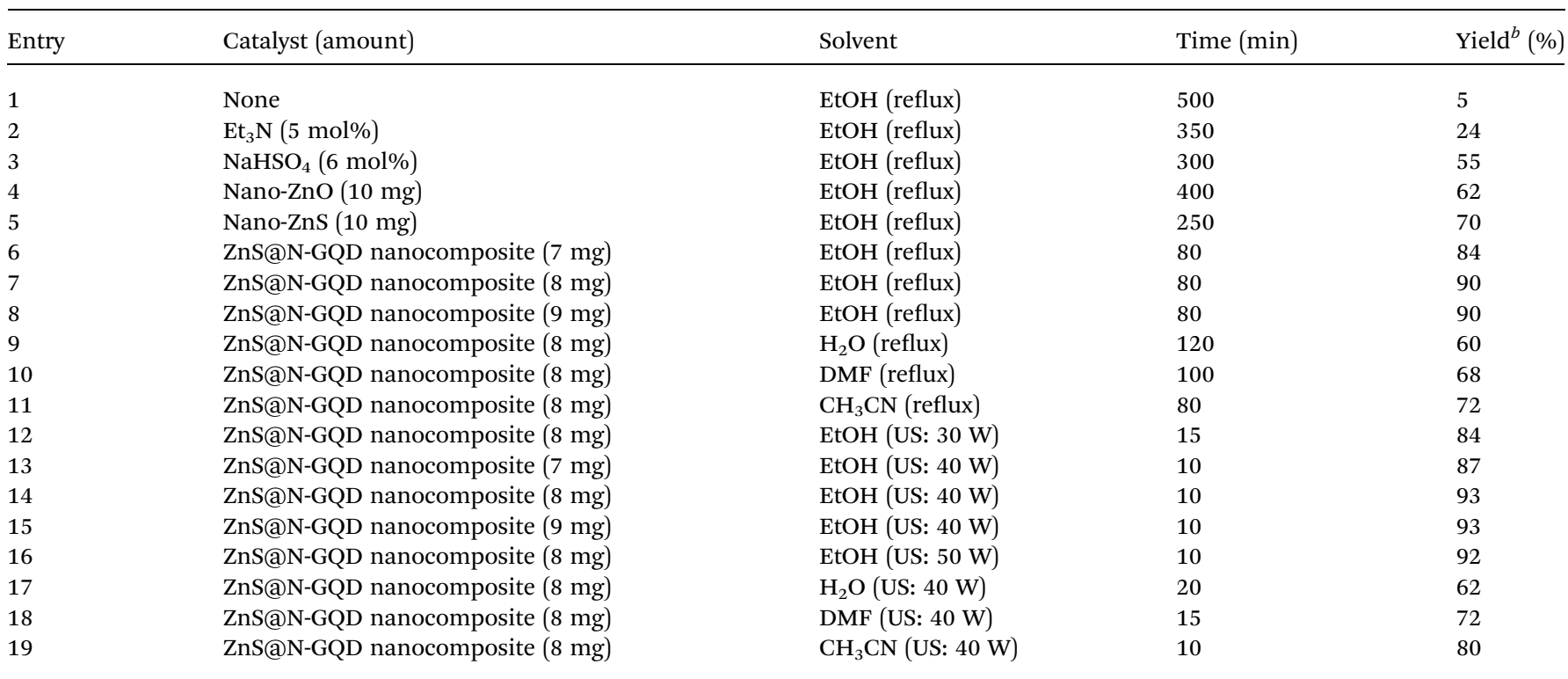

${ }^{a}$ Acetophenone $(1 \mathrm{mmol})$, benzaldehyde $(1 \mathrm{mmol})$ and aniline $(1 \mathrm{mmol}) .{ }^{b}$ Isolated yield. 
Table 3 Synthesis of $\beta$-amino carbonyls using the ZnS@N-GQD nanocomposite $\left(8 \mathrm{mg}\right.$ ) under ultrasonic irradiation ${ }^{a}$

Entry Aldehyde Aniline $\quad$ Product $(\mathbf{4 a}-\mathbf{4 h})$

$\mathrm{mp}\left({ }^{\circ} \mathrm{C}\right)$ (obtained)

1<smiles>O=Cc1ccccc1</smiles><smiles>Nc1ccccc1</smiles><smiles>O=Cc1ccccc1</smiles><smiles>Nc1ccc([N+](=O)[O-])cc1</smiles><smiles>O=C(CC(Nc1ccccc1)c1ccccc1)c1ccccc1</smiles><smiles>[141In]</smiles>

2<smiles>O=Cc1ccccc1</smiles><smiles>Cc1ccc(N)cc1</smiles><smiles>O=Cc1ccccc1O</smiles><smiles>Nc1ccc([N+](=O)[O-])cc1</smiles><smiles>O=C(CC(Nc1ccc([N+](=O)[O-])cc1)c1ccccc1O)c1ccccc1</smiles>

4d<smiles>O=Cc1ccc([N+](=O)[O-])cc1</smiles><smiles>Nc1ccc([N+](=O)[O-])cc1</smiles><smiles>O=C(CC(Nc1ccc([N+](=O)[O-])cc1)c1ccc([N+](=O)[O-])cc1)c1ccccc1</smiles>

$4 e$<smiles>O=Cc1ccccc1</smiles><smiles>Nc1ccc(Br)cc1</smiles><smiles>O=C(CC(Nc1ccc(Br)cc1)c1ccccc1)c1ccccc1</smiles>

12

160-62 
Table 3 (Contd.)

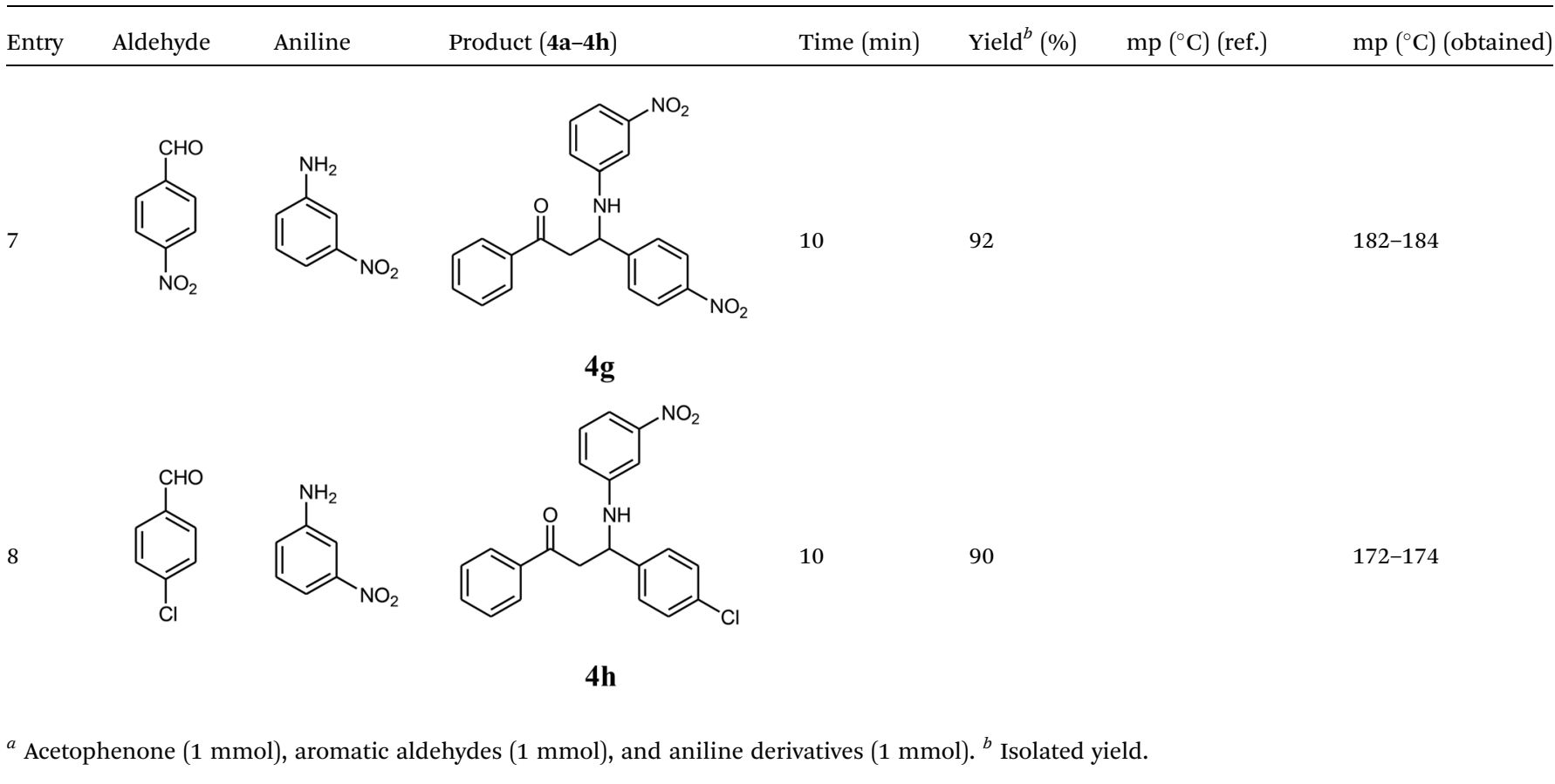

A plausible mechanism for the preparation of $\beta$-amino carbonyls using the ZnS@N-GQD nanocomposite is shown in Scheme 2. First, we assumed that the reaction occurs via a condensation between aniline and aldehyde to form intermediate I on the active sites of the ZnS@N-GQD nanocatalyst. Then, acetophenone was added to intermediate $\mathbf{I}$ to afford the product. This mechanism has been supported by literature. ${ }^{9,14}$

To compare the efficiency of the ZnS@N-GQD nanocomposite with the reported catalysts for the synthesis of $\beta$ amino carbonyls, we have tabulated the results in Table 4. As Table 4 indicates, the ZnS@N-GQD nanocomposite is superior with respect to the reported catalysts. As expected, the increased surface area due to the small particle size increased the reactivity of the catalyst. This factor is responsible for the accessibility of the substrate molecules on the catalyst surface. Our study has some advantages in comparison with previous studies

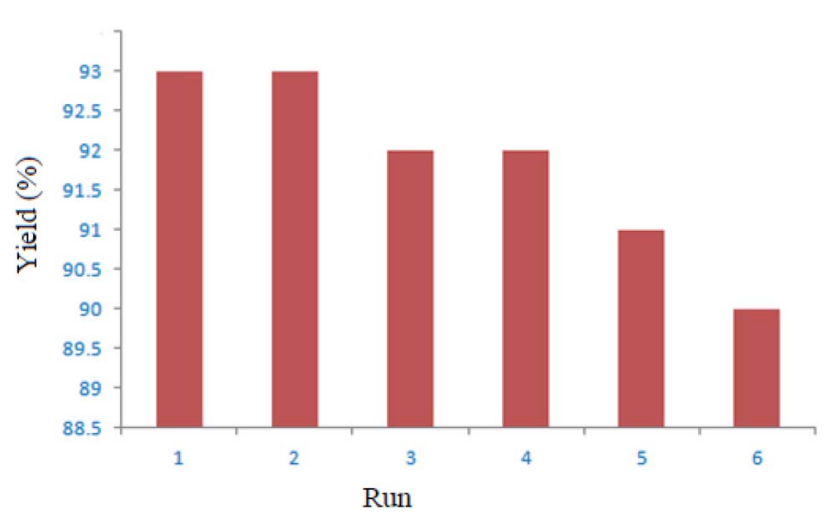

Fig. 7 Recycling of the ZnS@N-GQD nanocomposite as the catalyst for the model reaction. including high yield of the synthetic compound, reasonable time reaction and easy catalyst recovery.

\section{Experimental}

\subsection{Chemicals and apparatus}

NMR spectra were recorded on a Bruker Avance- $400 \mathrm{MHz}$ spectrometer in the presence of tetramethylsilane as the internal standard. The IR spectra were recorded on an FT-IR Magna 550 apparatus using $\mathrm{KBr}$ plates. Melting points were determined on Electrothermal 9200 and were not corrected. Powder X-ray diffraction (XRD) was performed on a Philips diffractometer of X'pert Company with monochromatized $\mathrm{Cu} \mathrm{K} \alpha$ radiation $(\lambda=$ $1.5406 \AA$ ). The microscopic morphology of the nanocatalyst was visualized by SEM (MIRA3). The thermogravimetric analysis (TGA) curves are obtained by V5.1A DUPONT 2000 .

\subsection{Preparation of nano-ZnS}

Nano-ZnS was prepared by simultaneously dropping $50 \mathrm{~mL}$ of $1 \mathrm{M}$ solution of zinc sulfate and $50 \mathrm{~mL}$ of $1 \mathrm{M}$ solution of sodium sulfide into $200 \mathrm{~mL}$ of distilled water containing $50 \mathrm{~mL}$

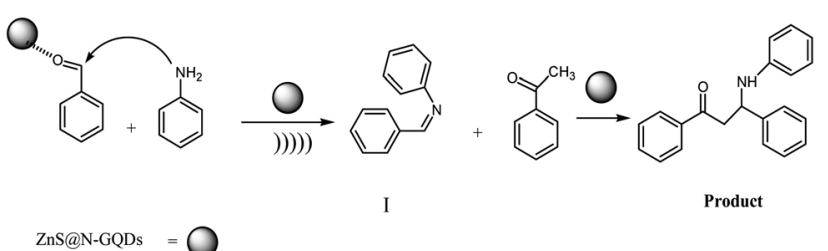

Scheme 2 A plausible mechanism for the preparation of $\beta$-amino carbonyls using the ZnS@N-GQD nanocomposite. 
Table 4 Comparison of the catalytic activity of the ZnS@N-GQD nanocomposite with other reported catalysts for the synthesis $\beta$-amino carbonyls

\begin{tabular}{|c|c|c|c|c|}
\hline Entry & Catalyst (condition) & Time (min) & Yield $^{a}, \%$ & Ref. \\
\hline 1 & $\mathrm{HClO}_{4}, 25 \mathrm{~mol} \%$, polyoxyethylene & 360 & 90 & 8 \\
\hline 2 & Phenyl boronic acid, $20 \mathrm{~mol} \%, \mathrm{CH}_{3} \mathrm{CN}$ & 640 & 88 & 9 \\
\hline 4 & Indium trichloride, $20 \mathrm{~mol} \%, \mathrm{H}_{2} \mathrm{O}$ & 200 & 70 & 11 \\
\hline 5 & Ceric ammonium nitrate (CAN), $5 \mathrm{~mol} \%$, PEG & 300 & 85 & 13 \\
\hline 6 & $\mathrm{BiCl}_{3}, 5 \mathrm{~mol} \%$, EtOH & 600 & 90 & 14 \\
\hline
\end{tabular}

of $0.1 \mathrm{M}$ solution of EDTA, which was vigorously stirred using a magnetic stirrer under Ar atmosphere. The precipitate was separated from the reaction mixture and was dried at room temperature.

\subsection{Preparation of the ZnS@N-GQD nanocomposite}

$1 \mathrm{~g}$ of citric acid was dissolved into $20 \mathrm{~mL}$ of deionized water and stirred to form a clear solution. Then, $0.3 \mathrm{~mL}$ of ethylenediamine was added to the above solution and mixed to obtain a clear solution. Furthermore, $0.1 \mathrm{~g}$ of $\mathrm{ZnS}$ nanoparticles was added to the mixture. The mixture was stirred at room temperature for $5 \mathrm{~min}$. The obtained solution was transferred into a $50 \mathrm{~mL}$ Teflon lined stainless autoclave. The sealed autoclave was heated to $180^{\circ} \mathrm{C}$ for $9 \mathrm{~h}$ in an electric oven. Finally, asprepared nanostructured ZnS@N-GQDs were obtained, washed several times with deionized water and ethanol, and then dried in an oven until constant weight was achieved.

\subsection{General procedure for the preparation of $\beta$-amino carbonyls}

A mixture of benzaldehyde $(1 \mathrm{mmol})$, aniline $(1 \mathrm{mmol})$, acetophenone $(1 \mathrm{mmol})$ and $8 \mathrm{mg}$ of the ZnS@N-GQD nanocomposite was stirred in $10 \mathrm{~mL}$ ethanol and was sonicated at $40 \mathrm{~W}$ power. After completion of the reaction (by TLC), the solution was filtered and the heterogeneous catalyst was recovered. Water was added, and the precipitate was collected by filtration and washed with water to give the pure product.

\section{Spectra data}

1,3-Diphenyl-3-phenylamino-propan-1-one (4a). White solid, $\mathrm{mp}$ 174-176 ${ }^{\circ} \mathrm{C}$; IR $\left(\mathrm{KBr}, \mathrm{cm}^{-1}\right)$ 1493, 1511, 1599, $(\mathrm{C}=\mathrm{C}$, aromatic), $1670\left(\mathrm{C}=\mathrm{O}\right.$, carbonyl), $3384(\mathrm{NH}$, second amine $) ;{ }^{1} \mathrm{H}$ $\mathrm{NMR}\left(400 \mathrm{MHz}, \mathrm{CDCl}_{3}\right): 3.55(\mathrm{~m}, 2 \mathrm{H}), 5.01(\mathrm{~m}, 1 \mathrm{H}), 6.61(\mathrm{~d}, 2 \mathrm{H}, J$ $=8 \mathrm{~Hz}), 6.71(\mathrm{t}, 1 \mathrm{H}, J=7.5 \mathrm{~Hz}), 7.10(\mathrm{t}, 2 \mathrm{H}, J=7.5 \mathrm{~Hz}), 7.26-7.32$ (m, 4H), 7.44-7.46 (m, 4H), $7.53(\mathrm{~m}, 1 \mathrm{H}), 7.89$ (d, 2H, J=8 Hz). ${ }^{13} \mathrm{C}$ NMR $\left(100 \mathrm{MHz}, \mathrm{CDCl}_{3}\right): \delta 46.30,54.82,113.85,117.80$, 126.39, 127.37, 128.21, 128.71, 128.83, 129.13, 133.44, 136.73, 142.98, 147.01, 198.28; anal. calc. for $\mathrm{C}_{21} \mathrm{H}_{19} \mathrm{NO}$ : C, 83.69; $\mathrm{H}$, 6.35 ; N, 4.65; found: C, 83.62; H, 6.27; N, 4.60.

3-(4-Nitrophenylamino)-1,3-diphenyl-propan-1-one (4b). White solid, mp 182-183 ${ }^{\circ} \mathrm{C}$; IR $\left(\mathrm{KBr}, \mathrm{cm}^{-1}\right)$ 1489, 1534, 1599, $(\mathrm{C}=\mathrm{C}$, aromatic), $1684\left(\mathrm{C}=\mathrm{O}\right.$, carbonyl), $3367\left(\mathrm{NH}\right.$, second amine); ${ }^{1} \mathrm{H}$ NMR (400 MHz, $\left.\mathrm{CDCl}_{3}\right): 3.55(\mathrm{~m}, 2 \mathrm{H}), 5.10(\mathrm{~m}, 1 \mathrm{H}), 6.52(\mathrm{~d}, 2 \mathrm{H}, J$
$=8 \mathrm{~Hz}), 7.07(\mathrm{~m}, 9 \mathrm{H}), 7.88(\mathrm{~d}, 2 \mathrm{H}, J=8 \mathrm{~Hz}), 7.99(\mathrm{~d}, 2 \mathrm{H}, J=8$ $\mathrm{Hz}) .{ }^{13} \mathrm{C} \mathrm{NMR}\left(100 \mathrm{MHz}, \mathrm{CDCl}_{3}\right): \delta 42.42,56.45,112.56,122.95$, 124.22, 127.10, 128.32, 128.94, 129.13, 131.34, 133.32, 136.14, 139.40, 143.67, 187.19. Anal. calc. for $\mathrm{C}_{21} \mathrm{H}_{18} \mathrm{~N}_{2} \mathrm{O}_{3}: \mathrm{C}, 72.82 ; \mathrm{H}$, 5.24; N, 8.09; found: C, 72.75; H, 5.26; N, 8.02.

1,3-Diphenyl-3-p-tolylamino-propan-1-one (4c). White solid, mp 165-166 ${ }^{\circ} \mathrm{C}$; IR ( $\left.\mathrm{KBr}, \mathrm{cm}^{-1}\right)$ 1519, 1526 (C=C, aromatic), 1678 ( $\mathrm{C}=\mathrm{O}$, carbonyl), 3400 ( $\mathrm{NH}$, second amine); ${ }^{1} \mathrm{H}$ NMR (400 $\mathrm{MHz}_{\mathrm{CDCl}}$ ): 2.19 (s, 3H, $\left.\mathrm{CH}_{3}\right), 3.53(\mathrm{~m}, 2 \mathrm{H}), 4.97(\mathrm{~m}, 1 \mathrm{H}), 6.38$ $(\mathrm{d}, 2 \mathrm{H}, J=8 \mathrm{~Hz}), 6.55(\mathrm{~d}, 2 \mathrm{H}, J=8 \mathrm{~Hz}), 6.90-7.56(\mathrm{~m}, 9 \mathrm{H}), 7.89$ (d, $2 \mathrm{H}, J=8 \mathrm{~Hz}) \cdot{ }^{13} \mathrm{C}$ NMR (100 $\left.\mathrm{MHz}, \mathrm{CDCl}_{3}\right): \delta 24.20,41.52$, $55.24,110.36,119.68,120.32,121.25,125.91,125.82,128.10$, $128.95,131.33,134.27,136.83,145.12,193.25$. Anal. calc. for $\mathrm{C}_{22} \mathrm{H}_{21} \mathrm{NO}: \mathrm{C}, 83.78 ; \mathrm{H}, 6.71$; N, 4.44; found: C, 83.68; H, 6.74; N, 4.49 .

3-(4-Nitrophenylamino)-3-(2-hydroxyphenyl)-1-phenylpropan-1one (4d). White solid, $\mathrm{mp} 160-162{ }^{\circ} \mathrm{C}$; IR $\left(\mathrm{KBr}, \mathrm{cm}^{-1}\right)$ 1297, 1469, $1597(\mathrm{C}=\mathrm{C}$, aromatic), $1664(\mathrm{C}=\mathrm{O}$, carbonyl), $3364(\mathrm{NH}$, second amine); ${ }^{1} \mathrm{H}$ NMR (400 MHz, $\left.\mathrm{CDCl}_{3}\right): 3.56(\mathrm{~m}, 2 \mathrm{H}), 5.41(\mathrm{~m}, 1 \mathrm{H})$, $6.51(\mathrm{~d}, 2 \mathrm{H}, J=8 \mathrm{~Hz}), 6.73-8.01(\mathrm{~m}, 12 \mathrm{H}), 9.83(\mathrm{~s}, 1 \mathrm{H}) .{ }^{13} \mathrm{C} \mathrm{NMR}$ $\left(100 \mathrm{MHz}, \mathrm{CDCl}_{3}\right): \delta 43.92,72.73,114.45,115.75,121.23,121.83$, 128.32, 128.52, 128.76, 128.86, 130.95, 133.25, 136.71, 136.84, 153.74, 154.12, 199.42. Anal. calc. for $\mathrm{C}_{21} \mathrm{H}_{18} \mathrm{~N}_{2} \mathrm{O}_{4}$ : C, 69.60; $\mathrm{H}$, 5.01; N, 7.73; found: C, 69.52; H, 4.94; N, 7.70.

3-(4-Nitrophenylamino)-3-(4-nitrophenyl)-1-phenylpropan-1-one (4e). White solid, mp 152-154 ${ }^{\circ} \mathrm{C}$; IR $\left(\mathrm{KBr}, \mathrm{cm}^{-1}\right)$ 1470, 1598 ( $\mathrm{C}=\mathrm{C}$, aromatic), 1657 ( $\mathrm{C}=\mathrm{O}$, carbonyl), 3344 ( $\mathrm{NH}$, second amine); ${ }^{1} \mathrm{H}$ NMR (400 MHz, $\left.\mathrm{CDCl}_{3}\right): 3.59(\mathrm{~m}, 2 \mathrm{H}), 5.21(\mathrm{~m}, 1 \mathrm{H})$, $6.50(\mathrm{~d}, 2 \mathrm{H}, J=8 \mathrm{~Hz}), 7.26-8.30(\mathrm{~m}, 12 \mathrm{H}) .{ }^{13} \mathrm{C} \mathrm{NMR}(100 \mathrm{MHz}$, $\left.\mathrm{CDCl}_{3}\right): \delta 48.52,72.68,114.25,120.84,121.93,127.45,128.85$, 129.35, 133.25, 136.75, 136.84, 146.52, 149.65, 153.82, 198.25. Anal. calc. for $\mathrm{C}_{21} \mathrm{H}_{17} \mathrm{~N}_{3} \mathrm{O}_{5}: \mathrm{C}, 64.45 ; \mathrm{H}, 4.38 ; \mathrm{N}, 10.74$; found: $\mathrm{C}$, $64.40 ; \mathrm{H}, 4.32$; N, 10.71 .

3-(4-Bromophenylamino)-1,3-diphenylpropan-1-one (4f). White solid, mp 178-180 ${ }^{\circ} \mathrm{C}$; IR $\left(\mathrm{KBr}, \mathrm{cm}^{-1}\right)$ 1529, 1596 (C=C, aromatic), $1685\left(\mathrm{C}=\mathrm{O}\right.$, carbonyl), $3372\left(\mathrm{NH}\right.$, second amine); ${ }^{1} \mathrm{H}$ NMR (400 MHz, $\left.\mathrm{CDCl}_{3}\right): 3.48(\mathrm{~m}, 2 \mathrm{H}), 4.95(\mathrm{~m}, 1 \mathrm{H}), 6.46(\mathrm{~d}, 2 \mathrm{H}, J$ $=8 \mathrm{~Hz}), 7.02(\mathrm{~d}, 2 \mathrm{H}, J=8 \mathrm{~Hz}), 7.23-7.57(\mathrm{~m}, 9 \mathrm{H}), 7.59(\mathrm{~d}, 2 \mathrm{H}, J=$ $7.8 \mathrm{~Hz}) .{ }^{13} \mathrm{C}$ NMR $\left(100 \mathrm{MHz}, \mathrm{CDCl}_{3}\right): \delta 48.56,72.54,111.42$, $115.35,126.50,127.10,128.52$, 128.95, 130.25, 132.54, 133.82, 136.74, 143.56, 146.85, 198.54. Anal. calc. for C, 66.33; H, 4.77 ; N, 3.68; found: C, 66.30; H, 4.71; N, 3.62. 
3-(3-Nitrophenylamino)-3-(4-nitrophenyl)-1-phenylpropan-1-one (4g). White solid, mp 182-184 ${ }^{\circ} \mathrm{C}$; IR $\left(\mathrm{KBr}, \mathrm{cm}^{-1}\right)$ 1314, 1518 $(\mathrm{C}=\mathrm{C}$, aromatic), $1683(\mathrm{C}=\mathrm{O}$, carbonyl), 3414 ( $\mathrm{NH}$, second amine); ${ }^{1} \mathrm{H}$ NMR (400 MHz, $\left.\mathrm{CDCl}_{3}\right): 3.56(\mathrm{~m}, 2 \mathrm{H}), 5.16(\mathrm{~m}, 1 \mathrm{H})$, $6.81(\mathrm{~d}, 1 \mathrm{H}, J=8 \mathrm{~Hz}), 7.42-7.66(\mathrm{~m}, 9 \mathrm{H}), 7.90(\mathrm{~d}, 2 \mathrm{H}, J=8 \mathrm{~Hz})$, $8.22(\mathrm{~d}, 2 \mathrm{H}, J=8 \mathrm{~Hz}) .{ }^{13} \mathrm{C} \mathrm{NMR}\left(100 \mathrm{MHz}, \mathrm{CDCl}_{3}\right): \delta 48.32,73.05$, 107.43 , 109.46, 119.82, 120.84, 127.68, 128.62, 128.37, 130.76, 133.25, 136.84, 146.48, 148.56, 149.28, 149.68, 199.14. Anal. calc. for $\mathrm{C}_{21} \mathrm{H}_{17} \mathrm{~N}_{3} \mathrm{O}_{5}$ : C, 64.45; H, 4.38; N, 10.74; found: C, 64.40; $\mathrm{H}, 4.32 ; \mathrm{N}, 10.71$.

3-(3-Nitrophenylamino)-3-(4-chlorophenyl)-1-phenylpropan-1one (4h). White solid, mp $172-174^{\circ} \mathrm{C}$; IR ( $\left.\mathrm{KBr}, \mathrm{cm}^{-1}\right)$ 1483, 1525 ( $\mathrm{C}=\mathrm{C}$, aromatic), $1668(\mathrm{C}=\mathrm{O}$, carbonyl), 3484 ( $\mathrm{NH}$, second amine); ${ }^{1} \mathrm{H}$ NMR (400 MHz, $\left.\mathrm{CDCl}_{3}\right): 3.49(\mathrm{~m}, 2 \mathrm{H}), 5.02(\mathrm{~m}, 1 \mathrm{H})$, $6.82(\mathrm{~d}, 2 \mathrm{H}, J=8 \mathrm{~Hz}), 7.19-7.61(\mathrm{~m}, 10 \mathrm{H}), 7.89$ (d, $2 \mathrm{H}, J=8 \mathrm{~Hz})$. ${ }^{13} \mathrm{C}$ NMR $\left(100 \mathrm{MHz}, \mathrm{CDCl}_{3}\right): \delta 49.43,72.45,107.43,109.64$, 119.64, 128.72, 128.83, 129.04, 129.24, 130.82, 132.58, 134.63, 136.85, 141.71, 148.83, 149.73, 198.54. Anal. calc. for $\mathrm{C}_{21} \mathrm{H}_{17} \mathrm{ClN}_{2} \mathrm{O}_{3}: \mathrm{C}, 66.23 ; \mathrm{H}, 4.50 ; \mathrm{N}, 7.36$; found: C, 66.23; $\mathrm{H}$, 4.48; Cl, 9.28; N, 7.32.

\section{Conclusions}

In conclusion, we have reported an efficient method for the synthesis of $\beta$-amino carbonyls using the ZnS@N-GQD nanocomposite as a superior catalyst under ultrasonic irradiation. The new catalyst is characterized by XRD, SEM, TEM, FT-IR spectroscopy, EDS, BET and TGA techniques. The salient features of this protocol are: great yields in concise times under sonication, retrievability of the nanocatalyst and little nanocatalyst loading.

\section{Conflicts of interest}

There are no conflicts to declare.

\section{Acknowledgements}

The authors are grateful to University of Kashan for supporting this work by Grant No. 159196/XXI.

\section{References}

1 S. Venkatesan, N. S. Karthikeyan, R. S. Rathore, P. Giridharan and K. I. Sathiyanarayanan, Med. Chem. Res., 2014, 23, 5086-5101.

2 G. X. Tang, J. F. Yan, L. Fan, J. Xu, X. L. Song, L. Jiang, L. F. Luo and D. C. Yang, Sci. China: Chem., 2013, 56, 490504.

3 R. Kenchappa, Y. D. Bodke, S. K. Peethambar, S. Telkar and V. K. Bhovi, Med. Chem. Res., 2013, 22, 4787-4797.

4 K. A. M. El-Bayouki, W. M. Basyouni, A. S. El-Sayed, W. M. Tohamy and A. A. El-Henawy, Croat. Chem. Acta, 2012, 85, 255-268.

5 H. L. Sham, D. J. Kempf, A. Molla, K. C. Marsh, G. N. Kumar, C. M. Chen, W. Kati, K. Stewart, R. Lal and A. Hsu, Antimicrob. Agents Chemother., 1998, 42, 3218-3224.
6 N. V. Makarova, E. I. Boreko, I. K. Moiseev, N. I. Pavlova, M. N. Zemtsova, S. N. Nikolaeva and G. V. Vladyko, Pharm. Chem. J., 2001, 35(9), 480-484.

7 Y. Du, Q. Li, B. Xiong, X. Hui, X. Wang, Y. Feng, T. Meng, D. Hu, D. Zhang, M. Wang and J. Shen, Bioorg. Med. Chem., 2010, 18, 4255-4268.

8 G. P. Lu and C. Cai, Catal. Commun., 2010, 11, 745-748.

9 S. V. Goswami, P. B. Thorat, A. V. Chakrawar and S. R. Bhusare, Mol. Diversity, 2013, 17, 33-40.

10 Y. Y. Yang, W. G. Shou and Y. G. Wang, Tetrahedron, 2006, 62, 10079-10086.

11 T. P. Loh, S. B. K. W. Liung, K. L. Tan and L. L. Wei, Tetrahedron, 2000, 56, 3227-3237.

12 B. C. Ranu, S. Samanta and S. K. Guchhait, Tetrahedron, 2002, 58, 983-988.

13 M. Kidwai, D. Bhatnagar, N. K. Mishra and V. Bansal, Catal. Commun., 2008, 9, 2547-2549.

14 H. Li, H. Y. Zeng and H. W. Shao, Tetrahedron Lett., 2009, 50, 6858-6860.

15 H. T. Luo, Y. R. Kang, H. Y. Nie and L. M. Yang, J. Chin. Chem. Soc., 2009, 56, 186-195.

16 X. C. Wang, L. J. Zhang, Z. Zhang and Z. J. Quan, Chin. Chem. Lett., 2012, 23, 423-426.

17 B. Kaur and H. Kumar, Org. Prep. Proced. Int., 2020, 52, 474477.

18 J. Qian, C. Shen, J. Yan, F. Xi, X. Dong and J. Liu, J. Phys. Chem. C, 2018, 122, 349-358.

19 P. Gao, K. Ding, Y. Wang, K. Ruan, S. Diao, Q. Zhang, B. Sun and J. Jie, J. Phys. Chem. C, 2014, 118, 5164-5171.

20 G. S. Kumar, U. Thupakula, P. K. Sarkar and S. Acharya, $R S C$ $A d v .$, 2015, 5, 27711-27716.

21 S. Zhu, J. Zhang, C. Qiao, S. Tang, Y. Li, W. Yuan, B. Li, L. Tian, F. Liu, R. Hu, H. Gao, H. Wei, H. Zhang, H. Sun and B. Yang, Chem. Commun., 2011, 47, 6858-6860.

22 D. Yang, X. Yao, J. Dong, N. Wang, Y. Du, S. Sun, L. Gao, Y. Zhong, C. Qian and H. Hong, Bioconjugate Chem., 2018, 29, 2776-2785.

23 S. Min, J. Hou, Y. Lei, X. Ma and G. Lu, Appl. Surf. Sci., 2017, 396, 1375-1382.

24 Y. Fu, G. Gao and J. Zhi, J. Mater. Chem. B, 2019, 7, 14941502.

25 N. Shaari, S. K. Kamarudin and R. Bahru, Int. J. Energy Res., 2021, 45, 1396-1424.

26 Z. Zeng, S. Chen, T. T. Y. Tan and F. X. Xiao, Catal. Today, 2018, 315, 171-183.

27 X. Li, M. Rui, J. Song, Z. Shen and H. Zeng, Adv. Funct. Mater., 2015, 25, 4929-4947.

28 S. Bak, D. Kim and H. Lee, Curr. Appl. Phys., 2016, 16, 11921201.

29 W. Chen, G. Lv, W. Hu, D. Li, S. Chen and Z. Dai, Nanotechnol. Rev., 2018, 7, 157-185.

30 H. Sun, L. Wu, W. Wei and X. Qu, Mater. Today, 2013, 16, 433-442.

31 P. Das, S. Ganguly, S. Banerjee and N. C. Das, Res. Chem. Intermed., 2019, 45, 3823-3853.

32 M. M. Khakzad Siuki, M. Bakavoli and H. Eshghi, Appl. Organomet. Chem., 2019, 33, 4774-4783. 
33 Y. M. A. Mohamed and Y. A. Attia, Appl. Organomet. Chem., 2020, 34, 5758-5770.

$34 \mathrm{H}$. Shahbazi-Alavi and J. Safaei-Ghomi, Nanochem. Res., 2019, 4, 55-63.

35 H. Shahbazi-Alavi, A. K. Abbas and J. Safaei-Ghomi, Nanocomposites, 2020, 6, 56-65.

36 G. Cravotto and P. Cintas, Chem. Soc. Rev., 2006, 35, 180-196.

37 T. J. Mason, A. J. Cobley, J. E. Graves and D. Morgan, Ultrason. Sonochem., 2011, 18, 226-230.

38 Z. Quan, Z. Wang, P. Yang, J. Lin and J. Fang, Inorg. Chem., 2007, 46, 1354-1360.

39 M. Muruganandham, R. Amutha, E. Repo, M. Sillanpää, Y. Kusumoto and M. Abdulla-Al-Mamun, J. Photochem. Photobiol., A, 2010, 216, 133-141.

40 P. Hu, G. Gong, F. Zhan, Y. Zhang, R. Li and Y. Cao, Dalton Trans., 2016, 45, 2409-2416.

41 A. M. Palve and S. S. Garje, Bull. Mater. Sci., 2011, 34, 667671.
42 H. Xie, C. Hou, H. Wang, Q. Zhang and Y. Li, Nanoscale Res. Lett., 2017, 12, 400-408.

43 J. N. Gavgani, A. Hasani, M. Nouri, M. Mahyari and A. Salehi, Sens. Actuators, B, 2016, 229, 239-248.

44 S. B. Maddinedi, B. K. Mandal, R. Vankayala, P. Kalluru, S. K. Tammina and H. A. K. Kumar, Spectrochim. Acta, Part A, 2014, 126, 227-231.

45 Y. Bian, B. He and J. Li, BioResources, 2016, 11, 6299-6308. 46 S. Kumar, A. K. Ojha, B. Ahmed, A. Kumar, J. Das and A. Materny, Mater. Today Commun., 2017, 11, 76-86.

47 X. Liu, C. Giordano and M. Antonietti, Small, 2014, 10, 193200.

48 S. Y. Liu, C. M. Zhen, Y. Z. Li, C. F. Pan, H. J. Zhou and D. L. Hou, J. Appl. Phys., 2012, 111, 053922-053927.

49 A. R. Massah, R. J. Kalbasi and N. Samah, Bull. Korean Chem. Soc., 2011, 32, 1703-1708. 